4. Aby uprawiać aktywnie turystykę sportową należy mieć dokładnie takie predyspozycje, kwalifikacje i specjalistyczny sprzęt, jaki jest dla danej dyscypliny sportu niezbędny. Inne będą wymagania dla sportów wodnych (żeglarstwo, wioślarstwo, windsurfing), dla sportów zimowych (snowbboard, narciarstwo, łyżwiarstwo), dla wspinaczki wysokogórskiej, a inne dla gry w golfa. Naturalnie część infrastruktury turystycznej podstawowej (baza noclegowa, gastronomiczna, transport, elementy bazy komplementarnej) pozostaje niezmienna, potrzebna turystom bez względu na uprawianą dyscyplinę sportową i rodzaj uczestnictwa.

5. Tradycyjnie sezonowość uprawiania wielu dyscyplin sportu łączyła się z konkretnymi wymaganiami topograficznymi i klimatycznymi. Obecnie mamy do czynienia z technologiami pozwalającymi na całoroczne uprawianie wielu dyscyplin sportu, niegdyś ściśle związanych z sezonowością i regionalizacją (LIPOŃSKI 2012). Oczywiście nic nie zastąpi romantyzmu w warunków naturalnych.

6. Wydaje się, że dla ułatwienia planowania badań nad turystyką sportową, osiągnięcia przejrzystej jej kategoryzacji i parametryzacji należy rozróżnić następujące segmenty problemowe: a) turystykę sportową bierną i czynną, b) podróż, której głównym celem jest uprawianie sportu, a nie inne przyczyny i motywy, c) podział na uczestniczących w turystyce sportowej zawodowców oraz amatorów (GAMMON, ROBINSON 2003, LOMINE, EDUMUNDS 2007, RITCHIE, ADAIR, red. 2004, UNWTO 2003).

Należy podkreślić, że turystyka sportowa (tak jak i inne formy turystyki) rzadko występuje w formie „czystej”. Można przypuszczać, iż jej uczestnicy będą w czasie wyjazdu brać udział także w turystyce poznawczej (kulturowej, krajoznawczej, edukacyjnej), biznesowej czy wypoczynkowej. Dlatego podejmowane próby definicji, badania oraz mierzenie skali uczestnictwa metodami statystycznymi może okazać się dosyć skomplikowane, bowiem trudno jest czasem wyróżnić motyw główny podróży (KORSTANJE 2007, RITCHIE, ADAIR, red. 2004, THEOBALD 2005).

Na zakończenie uwaga natury ogólnej na temat potencjalnego niebezpieczeństwa, jakie może nieść dążenie za wszelką cenę do ścisłego definiowania i kategoryzacji pojęć, które ze swojej natury leżą na pograniczu różnych zjawisk. Jest to często niemożliwe i w przypadku turystyki sportowej w efekcie prowadzić do nadmiernego rozszerzania (lub zawężenia) tego terminu, zniekształcania tego pojęcia i odbiegania od popularnego znaczenia przydawanego intuicyjnie w języku codziennym przez społeczeństwo.

\title{
Bibliografia
}

COOPer Ch., Fletcher J., Fyall A., Gilbert D., WAnhill S., 2005, Tourism. Principles and Practice, Prentice Hall, Harlow.

GAMMON S., ROBINSON T., 2003, Sport and Tourism: A Conceptual Framework, "Journal of Sport \& Tourism”, 8 (1), s. 21-26, DOI: 10.1080/14775080306236; marzec 2016.

GOŁEMBSKI G. (red.), 2002, Kompendium wiedzy o turystyce, Wyd. Naukowe PWN, Warszawa.

KORSTANJE M., 2007, The Origin and Meaning of Tourism: Etymological Study, „Review of Tourism Research” (eRTR), 5 (5), s. 100108, www.academia.edu/353007; marzec 2016.

KUREK W. (red.), 2007, Turystyka, Wyd. Naukowe PWN, Warszawa.

LIPOŃSKI W., 2001, Humanistyczna encyklopedia sportu, Oficyna Wydawnicza Atena, Poznań.

LIPOŃSKI W., 2012, Historia sportu, Wyd. Naukowe PWN, Warszawa.

LOMINE L., EdUMUNDS J., 2007, Key Concepts in Tourism, Palgrave Key Concepts, Palgrave - Macmillan, London.

RITCHIE B.W., ADAIR D. (red.), 2004, Sport tourism. Interrelationships, impacts and issues, ser. „Aspects of Tourism”, Channel View Publications, Toronto.

THEOBALD W.F., 2005, The Meaning, Scope and Measurment of Travel and Tourism, [w:] Global Tourism, Elsevier, London, s. 1-6.

UNWTO, 2003, Sport and Tourism - Introductory Report (English version), UNWTO eLibrary, DOI: 10.18111/9789284404179; marzec 2016.

UNWTO, 2012, Compendium of Tourism Statistics. Glossary of tourism terms, UNWTO eLibrary, DOI: 10.18111/9789284414338; marzec 2016.

http://dx.doi.org/10.18778/0867-5856.26.1.17

\author{
Alina Zajadacz \\ Uniwersytet im. A. Mickiewicza w Poznaniu \\ Wydział Nauk Geograficznych i Geologicznych \\ Katedra Turystyki i Rekreacji
}

\section{TURYSTYKA SPORTOWA - PRÓBA ZDEFINIOWANIA POJĘCIA}

Próba zdefiniowania pojęcia "turystyka sportowa" wymaga przypomnienia znaczenia podstawowych w tym przypadku terminów, takich jak „turystyka” oraz „sport”. Turystyka stanowi podzbiór podróży i jest definiowana jako „ogół czynności osób, które podróżują i przebywają w celach wypoczynkowych, służbowych lub innych nie dłużej niż przez rok bez przerwy poza swoim codziennym otoczeniem, z wyłączeniem wyjazdów, w których głównym celem jest działalność zarobkowa wynagradzana w odwiedzanej miejscowości (UNWTO 1991, za: KUREK, MIKA 2007, s. 12). Do podstawowych kryteriów identyfikacji wyjazdów turystycznych należy zatem: czasowa 
zmiana miejsca pobytu, zmiana środowiska (wyjazd poza codzienne otoczenie) oraz motywy wyjazdu (szczegółowo przedstawione w International Recommendations for Tourism Statistics 2008). Z kolei za sport są uznawane „wszelkie formy aktywności fizycznej, które przez uczestnictwo doraźne lub zorganizowane wpływają na wypracowanie lub poprawienie kondycji fizycznej i psychicznej, rozwój stosunków społecznych lub osiągnięcie wyników sportowych na wszelkich poziomach" (Ustawa z dnia 25 czerwca 2010 r. o sporcie).

W kontekście przywołanych definicji, w klasyfikacji rodzajów turystyki w oparciu o kryterium celu podróży, można wyróżnić turystykę sportową (sport tourism) rozumianą jako rodzaj podróży turystycznej, której głównym celem jest: aktywność fizyczna, udział w wydarzeniach sportowych lub zwiedzanie obiektów sportowych (GIBSON 1998, ROSS 2001, MOKRAS-GRABOWSKA 2015). Zróżnicowanie celów wyjazdów, jak również stopnia podejmowanej przez turystów aktywności fizycznej (tab. 1) powoduje, że nie można traktować turystyki sportowej jako zjawiska homogenicznego. Z punktu widzenia podmiotu turystyki sportowej - jakim jest turysta, udział w tego typu wyjazdach może $z$ jednej strony (skali aktywności) nie wymagać żadnych specjalnych predyspozycji fizycznych (zwiedzanie, obserwacja), ale z drugiej może być także związany z wyjazdami zawodowych sportowców.

Włączanie do wyjazdów turystycznych podróży sportowców-zawodowców (treningi, zawody) stanowi analogię do wyjazdów związanych z pracą w ramach turystyki biznesowej (STASIAK, WŁODARCZYK 2015).

Tab. 1. Klasyfikacja turystyki sportowej ze względu na cel wyjazdu

\begin{tabular}{|c|c|c|}
\hline Główny cel wyjazdu & Rodzaj turystyki & $\begin{array}{l}\text { Stopień aktywności } \\
\text { fizycznej }\end{array}$ \\
\hline Zwiedzanie obiektów sportowych & $\begin{array}{ll}- & \text { Turystyka sportowa nostaliczna } \\
\bullet & \text { Turystyka kibiców } \\
\checkmark & \text { Groundspotting }\end{array}$ & \multirow[t]{5}{*}{$\begin{array}{c}\text { mały } \\
\text { 个 }\end{array}$} \\
\hline $\begin{array}{l}\text { Wyjazdy ze sportowcami, podążanie za } \\
\text { sportowcami (bliskimi/idolami) }\end{array}$ & $\begin{array}{ll}\bullet & \text { Turystyka kibiców: } \\
\checkmark & \text { Turystyka sportowa eventowa }\end{array}$ & \\
\hline $\begin{array}{l}\text { Udział w wydarzeniach } \\
\text { sportowych }\end{array}$ & $\begin{array}{l}\text { Fanoturystyka } \\
\text { Groundhopping }\end{array}$ & \\
\hline $\begin{array}{l}\text { Podejmowanie aktyności fizycznej } \\
\text { amatorsko }\end{array}$ & $\begin{array}{ll}\text { - } & \text { Turystyka aktywna } \\
\text { - } & \text { Turystyka specjalistyczna } \\
\text { - } & \text { Turystyka kwalifikowana }\end{array}$ & \\
\hline Podejmowanie aktywności fizycznej zawodowo & Turystyka sportowców & \\
\hline
\end{tabular}

Groundspotting - zwiedzanie obiektów sportowych (poza imprezami sportowymi).

Groundhopping - „skakanie po boiskach” w celu wzięcia udziału w jak największej liczbie wydarzeń sportowych.

Źródło: opracowanie własne na podstawie: H.J. GIBSON (1998), S.D. ROSS (2001), J. MOKRAS-GRABOWSKA (2015), A. STASIAK, B. WŁODARCZYK (2015).

Duże zróżnicowanie nie tylko w odniesieniu do aktywności i sprawności fizycznej uczestników turystyki sportowej, ale także przedmiotów lub podmiotów ich zainteresowania (obiektów, wydarzeń, zespołów sportowych, zawodników-sportowców) powoduje, że bardzo trudno jest określić uwarunkowania rozwoju turystyki sportowej związane z rodzajem niezbędnej infrastruktury. Wyjazdy tego typu mogą nie wymagać żadnej infrastruktury (np. pływanie w jeziorze, wspinaczka wysokogórska), ale także mogą być wybitnie uzależnione od występowania określonego typu infrastruktury sportowej (np. zwiedzanie stadionów, uczestnictwo w masowych imprezach na stadionach, arenach, w halach sportowych).

Przedstawione zróżnicowanie rodzajów turystyki sportowej powoduje także duże trudności w pomiarze skali całości tego zjawiska, a także jego cech (m.in. sezonowości, struktury ruchu turystycznego, kierunków wyjazdów, miejsc koncentracji). Do podstawowych mierników w przypadku turystyki sportowej związanej z odwiedzaniem biletowanych obiektów, wykorzystaniem płatnych urządzeń (np. wyciągi narciarskie) czy uczestnictwem w imprezach należy liczba sprzedanych biletów. Monitorowanie zmian dotyczących frekwencji uczestników imprez odwiedzających obiekty, korzystających z infrastruktury pozwala na określenie skali tych form turystyki sportowej oraz ich zmienności w czasie. Źródłem danych na temat wyjazdów sportowców-zawodowców są organizacje, kluby sportowe (liczba wyjazdów, liczba sportowców, kierunki wyjazdów, czas pobytu, sezonowość, koszty wyjazdu itp.), jak również obiekty noclegowe, czyli zakwaterowanie dla sportowców. Najtrudniej określić skalę zjawiska turystyki sportowej związaną z aktywnością amatorów, niewymagającą płatnej infrastruktury. Wyłonienie tego typu turystów spośród ogółu podróżujących wymaga badań nad rozpoznaniem motywów podróży.

Obserwowane coraz większe zróżnicowanie rodzajów turystyki, które można określić mianem turystyki sportowej, szybki wzrost ich popularności (np. maratonów, rajdów, wyjazdów typu groundspotting, groundhopping) stanowi odzwierciedlenie zmian zachodzących w stylu życia współczesnego społeczeństwa nastawionego w coraz większym stopniu na aktywność fizyczną. W połączeniu z prognozami rozwoju turystyki (Tourism towards 2030) można spodziewać się w najbliższej przyszłości dalszego rozwoju turystyki sportowej i w sensie ilościowym (mierzonym liczbą uczestników), i jakościowym (mierzonym coraz większym zróżnicowaniem jej form). 


\section{Bibliografia}

International Recommendations for Tourism Statistics 2008, UNWTO, Madrid.

KUREK W., MIKA M., 2007, Problem definicji turystyki, [w:] Turystyka, W. Kurek (red.), Wyd. PWN, Warszawa, s. 11-16.

GIBSON H.J., 1998, Sport tourism: a critical analysis of research, „Sport Management Review”, 1, s. 45-76.

MOKRAS-GRABOWSKA J., 2015, Turystyka aktywna - zagadnienia terminologiczne i klasyfikacje, [w:] Wczoraj, dziś i jutro turystyki aktywnej i specjalistycznej, A. Stasiak, J. Śledzińska, B. Włodarczyk (red.), Wyd. PTTK „Kraj”, Warszawa, s. 11-25.

Ross D., 2001, Developing Sports Tourism. An eGuide for Destination Marketers and sports Events Planners, National Laboratory for Tourism and eCommerce. University of Ilinois at Urbana Champaign, http://www.lib.teiher.gr/webnotes/sdo/Sport\% 20Tourism/Sport-Tourism\%20Development\%20Guide.pdf; 8.04.2016.

STASIAK A., WŁODARCZYK B., 2015, Czy turystyka może nie być aktywna? O potrzebie podziałów i klasyfikacji turystyki, [w:] Wczoraj, dziś i jutro turystyki aktywnej i specjalistycznej, A. Stasiak, J. Śledzińska, B. Włodarczyk (red.), PTTK „Kraj”, Warszawa, s. 39-51.

Tourism towards 2030. Global Overview, UNWTO, 2011, http://www.e-unwto.org/doi/book/10.18111/9789284414024; 8.04. 2016.

Ustawa z dnia 25 czerwca 2010 roku o sporcie, Dz. U. z 2014 r. poz. 715, z 2015 r. poz. 1321. 